\title{
UJI STABILITAS FORMULASI KRIM TABIR SURYA SERBUK RUMPUT LAUT (Eucheuma cottonii. Doty)
}

\author{
Hamsinah $^{1}$, Sasanti D. Darijanto ${ }^{2}$, Rachmat Mauluddin ${ }^{2}$ \\ ${ }^{1}$ Fakultas Farmasi, Universitas Muslim Indonesia, \\ ${ }^{2}$ Sekolah Farmasi, Institut Teknologi Bandung \\ ${ }^{1}$ hamsinah.hamsinah@umi.ac.id
}

\begin{abstract}
Over sunlight exposure in long periode may cause skin damage, premature aging, and skin cancer possibilitie. Sunsreen can protect the skin from negative effect of sunlight, it can reduce the negative effect of UV radiation. Seaweed powder Eucheuma cottonii. Doty is one of the sea plants that can be used as a sunscreen. The objective of this research was to evaluate the physical stability of cream seaweed powder (Eucheuma cotonii. Doty). Cream evaluation included organoleptic, pH, viscosity, freeze an thaw, and sentrifuge test. The organoleptic examination that has been done does not change the smell, color, fungal growth, and does not form a layer on the surface of the creams, and creams remain homogeneous. Emulsion type of preparation was the water in oil. The effect of storage time on viscosity creams are not significant changes. The result sentrifuge test at a speed of 3800 rpm for 5 hours showed the cream to remain stable, and there was no phase separation. Cream storage at two different temperatures or freeze thaw cycle was stable there were no phase separation until the cycle to six.
\end{abstract}

Keywords: Seaweed powder, tipe of emulsion W/O, test stability of physical cream.

\section{PENDAHULUAN}

Sediaan tabir surya dikelompokkan dalam kosmetik dan didefinisikan sebagai sediaan yang mengandung bahan aktif yang mampu menyerap, membelokkan, atau menghamburkan radiasi sinar matahari, terutama di daerah emisi gelombang ultraviolet dan inframerah, terutama radiasi UV B pada panjang gelombang 290- $340 \mathrm{~nm}$ (Depkes RI, 1985). Beberapa sediaan tabir surya efektif mengurangi jumlah radiasi UV B, tetapi masih dapat meneruskan sejumlah besar radiasi UV A (UV A I 340-400 nm dan UV A II 320-340 nm). Penggunaan tabir surya digunakan untuk mencegah dampak negatif radiasi sinar ultraviolet dengan menggunakannya sebelum terpapar sinar matahari.

Paparan sinar UV yang terus menerus dalam jangka panjang dapat menyebabkan kulit keriput, bercak-bercak hitam dan kemungkinan dapat menyebabkan kanker kulit. Tabir surya bermanfaat untuk mencegah kulit terbakar, karena secara kimia dapat merubah energi sinar UV yang diabsorbi menjadi panas kemudian akan dilepaskan. Tabir surya fisik yang bekerja dengan cara memantulkan sinar matahari adalah titanium dioksida ultrafine dan seng oksida ultrafine, tergantung ukuran partikel dan luas permukaan penggunaan (Takeda dkk., 2001).

Rumput laut Eucheuma cottonii. Doty adalah tumbuhan laut yang kandungan utamanya adalah kappa karagenan yang berpotensi sebagai pelindung surya dan nutrisi. Karagenan dalam Eucheuma cottonii. Doty berpotensi sebagai proteksi UV B dan antioksidan (Thevanayagam, H., dkk, 2013). Dalam kosmetik karagenan bisa diformulasi dalam produk tabir surya, krim antiaging, dan facial creams (Campo et al, 2009; Necas and Bartosikova (2013).

Rumput laut Eucheuma cottonii. Doty diformulasi menjadi tabir surya dapat meminimalisir dampak negative dari paparan sinar matahari yang berlebihan. Sediaan pelindung surya yang akan digunakan oleh konsumen harus memenuhi persyaratan farmaseutika terutama dalam hal stabilita fisik dan kimia, tidak mempengaruhi metabolisme tubuh, tidak menyebabkan iritasi dan toksisitas terhadap kulit. Faktor-faktor yang mempengaruhi efektivitas sediaan pelindung surya di antaranya adalah $\mathrm{pH}$, jenis atau tipe sediaan, keamanan penggunaan sediaan, tebal lapisan pada kulit, dan kestabilan sediaan selama penggunaan. Tujuan penelitian ini adalah untuk mengevaluasi stabilitas fisik sediaan krim tabir surya serbuk rumput laut Eucheuma cottonii. Doty

\section{METODE PENELITIAN}

A. Alat

Spatula, batang pengaduk, labu ukur (Pyrex), gelas ukur (Pyrex), lemari pendingin, kaca arloji, thermometer, object glass, mikroskop polarisasi (Olympus BX-50), bath sonicator (Branson tipe 5510), ultraturax T25 (Janke \& Kunkle, IKA labortecchnik), timbangan analitik (Taledo), Viskometer Helipath Stand Spindle 
Ranges for $\mathrm{RV}, \mathrm{pH}$ meter (Beckmann), sentifuge, Oven, $\mathrm{pH}$ meter.

\section{B. Bahan}

Simplisia serbuk rumput laut Eucheuma cottonii. Doty, Virgin Coconut Oil (VCO), setomakrogol 1000, setostearil alkohol, propil paraben, metil paraben, propilen glikol, tokoferol asetat, lavender essence, aquadeion, dan metilen blue.

\section{Prosedur Penelitian}

1. Pengamatan Organoleptis

Pengamatan organoleptis terhadap sediaan krim tabir surya dilakukan selama masa penelitian meliputi bau, warna, pertumbuhan jamur, terbentuk lapisan pada permukaan krim, dan homogenitas.

\section{Tipe Emulsi}

Tipe emulsi dievaluasi dengan mengoleskan sediaan krim di atas kaca objek dan kemudian ditambah larutan metilen birudalam air kemudian diamati di bawah mikroskop polarisasi. Tipe emulsi merupakan air dalam minyak apabila fase air terwarnai oleh metilen biru.

\section{Evaluasi Kestabilan Krim}

\section{Uji Sentrifugasi}

Sebanyak 10 gram krim dimasukkan ke dalam tabung sentrifuga, disentrifuga pada suhu ruang $25^{\circ} \mathrm{C}$ dengan kecepatan 3800 selang waktu 30 menit selama 5 jam. Sistem emulsi yang stabil menunjukkan tidak terjadinya pemisahan fase setalah disentrifuga. Kecepatan $3800 \mathrm{rpm}$ mengindikasikan bahwa sediaan stabil selama setahun pada suhu ruang (Lachman, Lieberman, and Kanig, 1986).

\section{Uji Freeze - Thaw}

Penyimpanan pada siklus freeze thaw dilakukan untuk melihat stabilita fisik krim setelah disimpan selama tiga puluh hari pada suhu yang berbeda yaitu $4^{\circ} \mathrm{C}$ dan $40^{\circ} \mathrm{C}$. Penyimpanan dilakukan dalam enam siklus dan satu siklus berlangsung selama tiga hari pada masing-masing pada masing-masing suhu. Krim ditimbang \pm 2 gram, dimasukkan ke dalam beberapa vial dan disimpan dalam lemari es (suhu $4^{\circ} \mathrm{C}$ ) selama tiga hari, kemudian dilanjutkan dengan menyimpan sediaan di dalam climatic chamber (suhu $40^{\circ} \mathrm{C}$ ) pada waktu yang sama. Kemudian diamati keterpisahan fasenya.

\section{Homogenitas Sediaan}

Homogenitas krim dievaluasi dengan mengoleskan sediaan pada permukaan kaca objek kemudian disebarkan dengan bantuan kaca objek yang lain untuk mendapatkan permukaan yang homogen.

\section{Uji pH}

Sediaan yang memiliki kestabilan fisik yang baik diukur $\mathrm{pH}$-nya dengan $\mathrm{pH}$ meter Beckman. Dilakukan dengan cara mencelupkan elektroda $\mathrm{pH}$ ke dalam setiap batch sediaan krim tabir surya. Setelah elektroda tercelup, $\mathrm{pH}$ meter dinyalakan kemudian didiamkan hingga layar pada $\mathrm{pH}$ meter menunjukkan angka yang stabil. Pengukuran $\mathrm{pH}$ dilakukan pada hari ke $0,1,7,14$, 21, dan 28.

\section{Uji Viskositas}

Sediaan diukur viskositasnya dengan menggunakan Viskometer Helipath Stand Spindle Ranges for RV dengan spindel TC dan putaran 5 rpm. Pengukuran viskositas dilakukan pada hari ke $0,1,7,14,21$, dan 28 .

\section{HASIL DAN PEMBAHASAN}

\section{A. Uji organoleptis dan penentuan tipe Emulsi}

Krim diperiksa parameter perubahan organoleptisnya selama 28 hari penyimpanan pada suhu ruang dan pengamatan dilakukan setiap tujuh hari (seminggu). Hasil pemeriksaan menunjukkan semua krim tidak mengalami perubahan bau, warna, pertumbuhan jamur, dan tidak terbentuk lapisan pada permukaan krim, serta krim tetap homogen. Hasil penentuan tipe emulsi krim yang di formula menunjukkan tipe emulsi sediaan krim adalah air dalam minyak. Pada penentuan tipe emulsi digunakan metilen biru yang larut dalam air. Hasil pengamatan menunujukkan metilen biru terwarnai pada fase dalam krim, sehingga dapat disimpulkan, tipe emulsi sediaan adalah air dalam minyak. 
Tabel 2. Pengamatan Penampilan Fisik Formula Krim

\begin{tabular}{ccccc}
\hline \multicolumn{2}{c}{ Pengamatan } & Formula \\
\hline Organoleptik & Bau & A & B & C \\
& Warna & - & - & - \\
Homogenitas & Pertumbuhan Jamur & - & - & - \\
Tipe Emulsi & Pengenceran dengan: & Baik & \\
& Air & Larut & \\
& Minyak & Tidak larut \\
& Pewarna dengan & & Warna biru berada \\
Metilen biru & & ditengah & \\
\hline
\end{tabular}

Berikut adalah gambar homogenistas krim dan tipe emulsi air dalam minyak

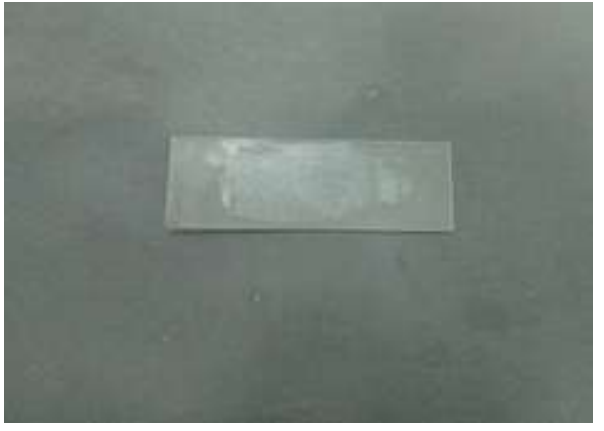

a. gambar homogenitas krim

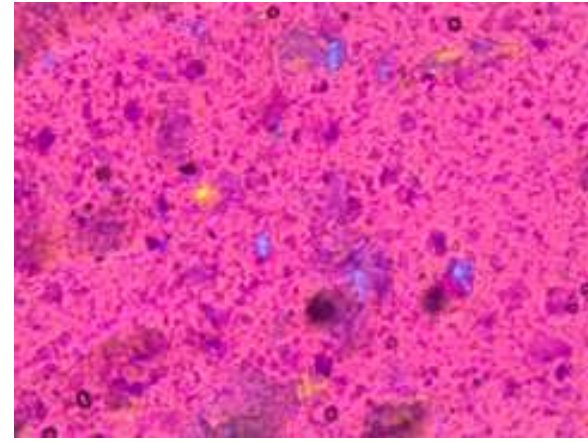

b. gambar tipe emulsi A/M

Gambar 1. (a) Evaluasi homogenitas krim serbuk rumput laut Eucheuma cottonii. Doty (b) Emulsi air dalam minyak di bawah mikroskop polarisasi dengan perbesaran 200x

\section{B. Uji Sentrifugasi}

Kestabilan fiisik krim selanjutnya dievaluasi dengan motode sentrifugasi pada kecepatan $3800 \mathrm{rpm}$ selama 5 jam. Hasil evaluasi menunjukkan semua formula stabil setelah sentrifugasi. Selanjutnya kecepatan ditingkatkan sampai $6000 \mathrm{rpm}$ selama 5 jam dengan selang waktu masing-masing 30 menit. Hasil evaluasi menunjukkan formula tersebut tetap stabil, tidak ada keterpisahan fase. Berdasarkan evaluasi tersebut, krim yang dibuat stabil terhadap gaya gravitasi selama 1 tahun penyimpanan pada suhu kamar (Lachman, Lieberman, and Kanig, 1986).

\section{Uji Freeze Thaw}

Penyimpanan krim pada dua suhu yang berbeda atau siklus freeze thaw untuk melihat pengaruh suhu terhadap pemisahan fase krim. Dari hasil pengamatan terlihat bahwa krim formula FIZ 14 stabil tidak ada keterpisahan fase sampai pada siklus ke enam. Proses freeze thaw dapat berhasil atau tidak terjadi pemisahan fase tergantung dari kemampuan krim untuk segera pulih dari tekanan air kristal. Pada proses freeze, terbentuk kristal air yang memiliki struktur lebih teratur dan rapat sehingga krim tidak dapat mengalir. Saat suhu $4{ }^{\circ} \mathrm{C}$ fase air membeku dan cenderung menyusut, sehingga terjadi penyempitan ruang fase air dan menyebabkan globul minyak saling berdekatan atau cenderung bergabung membentuk ikatan antar partikel yang lebih rapat, akibatnya kekentalan sediaan jadi meningkat (Martin, 1993). Pada proses thaw, kristal akan mencair dan akan kembali menyebar pada sistem. Jika kecepatan pemulihan dari krim lambat maka dapat terjadi ketidakstabilan.

\section{Uji Viskositas}

Pengujian viskositas krim dilakukan secara triplo. Pengujiannya dilakukan pada suhu kamar dan diamati setiap minggunya. Hasil pengamatan menunjukkan bahwa formula krim mengalami perubahan viskositas.

Tabel 3.Viskositas Krim selama Penyimpanan pada suhu Ruang

\begin{tabular}{cc}
\hline Hari ke - & Krim \\
\hline $\mathbf{0}$ & $31600,00 \pm 1058,30$ \\
\hline $\mathbf{1}$ & $33333,33 \pm 1222,02$ \\
\hline $\mathbf{7}$ & $36800,00 \pm 800,00$ \\
\hline $\mathbf{1 4}$ & $41600,00 \pm 400,00$ \\
\hline $\mathbf{2 1}$ & $44400,00 \pm 1200,00$ \\
\hline $\mathbf{2 8}$ & $45866,67 \pm 461,88$ \\
\hline
\end{tabular}


Hasil evaluasi viskositas menunujukkan visositas krim meningkat dengan meningkatnya konsentrasi sebuk Eucheuma cottonii. Doty dan lama waktu penyimpananan. Hal ini disebabkan karena zat aktif berupa sebuk Eucheuma cottonii. Doty yang mengandung karagenan dapat mengembang dengan adanya air dalam sediaan selama penyimpanan. Dari analisis statistik yang dilakukan dapat disimpulkan bahwa pengaruh waktu penyimpanan terhadap viskositas krim tidak terjadi perubahan yang signifikan $(p \leq 0,05)$. Jika konsentrasi karagenan meningkat maka viskositas akan meningkat karena dapat menarik air lebih banyak. Semakin tinggi nilai viskositas maka semakin tinggi pula kekentalannya. Kekentalan pada karagenan disebabkan adanya daya tolak-menolak antara grup sulfat yang bermuatan negatif, yang terdapat pada sepanjang rantai polimernya sehingga menyebabkan rantai polimer tersebut kaku dan tertarik kencang (Guiseley, 1980). Semakin kecil kandungan sulfat, maka nilai viskositasnya juga semakin kecil, tetapi kekuatan gelnya semakin meningkat. Adanya garam-garam yang terlarut dalam karagenan akan menurunkan muatan sepanjang rantai polimer (Moirano, 1977). Penurunan muatan ini menyebabkan penurunan gaya tolakan antar gugus-gugus sulfat, sehingga sifat hidrofilik polimer semakin lemah dan menyebabkan viskositas larutan menurun. Viskositas karagenan akan menurun seiring dengan peningkatan suhu sehingga terjadi depolimerisasi yang kemudian dilanjutkan dengan degradasi karagenan (Towle, 1973).

\section{E. Uji pH}

Hasil evaluasi pH menunjukkan adanya perubahan $\mathrm{pH}$ selama penyimpanan pada suhu ruang tapi tidak memberikan perbedaan yang signifikan dan masih berada dalam batasan $\mathrm{pH}$ kulit yaitu pada rentang 4 hingga 6,5 .

Tabel 4. pH krim selama penyimpanan pada Suhu Ruang

\begin{tabular}{cc}
\hline Hari ke - & Formula \\
\hline $\mathbf{0}$ & $5,78 \pm 0,07$ \\
\hline $\mathbf{1}$ & $5,89 \pm 0,05$ \\
\hline $\mathbf{7}$ & $5,96 \pm 0,02$ \\
\hline $\mathbf{1 4}$ & $6,04 \pm 0,02$ \\
\hline $\mathbf{2 1}$ & $6,13 \pm 0,02$ \\
\hline $\mathbf{2 8}$ & $6,20 \pm 0,06$ \\
\hline
\end{tabular}

\section{KESIMPULAN}

Berdasarkan hasil penelitian yang telah dilakukan dapat disimpulkan bahwa krim serbuk rumput laut (Eucheuma cottonii. Doty) stabil secara fisik.

\section{DAFTAR PUSTAKA}

Campo, V.L., Kawano, D.F., Silva Junior, D.B., Ivone Carvalho, I. (2009), Carrageenans: Biological Properties, Chemical Modifications and Structural Analysis, Carbohydrate Polymers,77, 167-180.

Ditjen POM Depkes RI.(1986): Formularium Kosmetika Indonesia, Depkes RI, Jakarta, 399-425.

Guiseley,K.B., Stanley, N.F., Whitehouse, P.A. (1980) : Carrageenan Hand Book of Water Soluble Gums and Resin. Toronto, London : Mc Graw Hiill Book Company, New York, 125-142.

Lachman, L.,H.A. Lieberman. (1986): The Theory and Practice of Industry Pharmacy, $3^{\text {rd }}$ ed. Lea and Febriger. Philadelpia.535 - 561.

Moirano, A.L. (1977): Sulfate Seaweed Polysacharides in Food Colloids. The AVI Publ.co.Wesport Conneticut. 347-381.

Takeda, K., Harada, S. dan. N Ando, M., (2001): UV Care Cosmetic. Functional Cosmetology Substantiation of Cosmetic Efficacy, Recent progress and future promise, Society of Cosmetic Chemists of Japan. 126 - 144.

Towle, G.A., (1973): Carrageenan. Industrial Gums. Second edition. Academik Press. New York, 83- 114. 